\title{
The impact of Covid-19 outbreak on United Kingdom infrastructure sector
}

\author{
Haddy Jallow ${ }^{1}$, Suresh Renukappa ${ }^{2}$, and Subashini Suresh ${ }^{2}$ \\ ${ }^{1}$ BIM Co-ordinator \\ A14 Integrated Delivery Team, \\ Costain Plc, London, United Kingdom \\ ${ }^{2}$ Faculty of Science and Engineering, \\ University of Wolverhampton, \\ Wolverhampton, United Kingdom
}

\begin{abstract}
Purpose: In December 2019, news broke out from the World Health Organisation (WHO), with the first outbreak of Covid-19 in Wuhan China. On March 11 2020, the WHO declared Covid-19 to officially be a pandemic. The UK was put under lockdown on the $23^{\text {rd }}$ of March 2020 by the Prime Minister Boris Johnson, the lockdown introduced strict measures put into place including the restriction for unnecessary working from offices, and only leaving houses if it is deemed essential. Therefore, this paper focuses on the changes that the infrastructure sector has had to undertake in order to adhere to the Covid-19 lockdown rules while being productive.
\end{abstract}

Design/methodology/approach: Given the new and unexplored nature of the research problem, a qualitative research methodology was adopted. In total, five semi-structured interviews from three infrastructure sector organisations were conducted to collect data, which was then analysed using thematic analysis for inference and conclusion.

Findings: The results indicate that the lockdown is proving to be difficult to manage projects as staff members are working from home. This leads to delays on a project activities as many staff cannot physically go on site and conduct works. The managers are finding difficult to manage their teams. However, technological tools such as video chat and meetings via online platforms have proven to be most effective in communications with project teams. The Building Information Modelling (BIM)/Design has been useful as the 3D design models helps to visualise the project within team meetings in order to comply with the Covid-19 rules and follow social distancing guidelines while still carrying on works. However, induction to any new starter is proving to be difficult to manage with the pandemic and lockdown as it involves a drugs and alcohol test prior to commencing work of that project.

Originality/value: This paper provides a rich insight into the understanding and awareness of the impact of Covid-19 and the changes that the infrastructure sector has had to undertake in order to adhere to the lockdown rules while being productive. This study contributes towards informing policymakers on some lessons learned from the management of the Covid-19 from an infrastructure sector perspective. Furthermore, twelve key implications are drawn for decision makers within the infrastructure sector business to rethink and act to deal with the pandemic crisis.

Keywords: Covid-19, impact, infrastructure sector, cultural change, social distancing, and lock down. 


\section{Introduction}

The physical infrastructure sector is at a peak in terms of creating new infrastructure for the world. Infrastructure forms an essential part of our daily lives and is vital for creating economic prosperity and maintaining society's health and well-being (ICE, 2013; Grigg, 2010). Infrastructure is the organisational backbone of an economy (Weber and Alfen, 2016). The UK government planned on providing improved infrastructure with their Nation Infrastructure Development Plan (NIDP) back in 2016 in order to gain a more productive economy and better the society for the future (HM Treasury and Cabinet Office, 2016). The HM Treasury (2013) report on national infrastructure in the UK identified significant vulnerabilities, capacity limitations and a number of national infrastructure components nearing the end of their useful life. Helm, et al., (2010) noted that the UK needed a total of $£ 434 \mathrm{bn}$ of new investment into transport ( $£ 120 \mathrm{~b})$, energy (£264b), water (£45b) and telecommunications $(£ 5 b)$ related infrastructure over a period of time. Furthermore, their report warns that the true figure could be nearer to £500bn over the next ten years. The National Infrastructure Delivery Plan 2016 (HM Treasury and Cabinet Office, 2016) has stated the aims for the progress expected by the end of 2020 and early 2021 with the infrastructure building plan.

Over 100 major road construction which includes the addition of over 1300 lane mileage is expected to be constructed and up and running by 2021 (HM Treasury and Cabinet Office, 2016). The rail sector is also being invested on with a major improvement in rail across the country; it is safe to say that the infrastructure sector has a lot of work over the next few years. The infrastructure industry needs to step forward and develop solutions with the public sector and create new physical infrastructure procurement and management models that will underpin mutual goals (Akintoye and Renukappa, 2013). However, public policy makers are increasingly aware that the current Covid-19 and economic downturn provide a significant opportunity for major change in the way public infrastructure and services are funded and delivered.

In December 2019, reports of the first Covid-19 case were discovered. At the start of Covid19 , notably many global citizens would have been in China, be it for business or traveling for leisure, with this being the case, Covid-19 quickly made its way to many different countries through the travelling population (Kynge and Lockett, 2020). As it is a new virus, there is no cure or vaccine. This brought the world to a halt as uncertain times came ahead.

\section{Theoretical background}

\section{UK infrastructure sector}

\section{Roads}

Having a reliable and high-quality road network helps in improving productivity within a society as with missing links on the road network or congestion can massively impact the economy. In 2015, the UK government established "Highways England (HE)" in order to maintain and improve the motorways and A roads within England, HE have invested in delivering new and improved roads to provide efficiency and provide the best results for tax payers. By the end of 2020 and beginning of 2021, the UK government aims to have 
completed the production of over 100 major road projects which includes the addition of over 1300 lane mileage construction and the rework of 60 major junctions which have been problematic. As part of the strategy, the aim for 2020 is to complete:

- Smart Motorways: These have been implemented to battle congestion and improving capacity of the motorways, by the end of 2020, the aim is to complete Smart motorways including the M1, M3, M20, M23 and M6 (HM Treasury and Cabinet Office, 2016).

- A14: This is a $£ 1.5$ billion investment which includes a 21 mile stretch between Huntingdon and Cambridge. This project involves the widening of sections of the road network and junction improvement.

- A1 (North): This is a $£ 1$ billion project which includes the improvement and maintenance of the stretch of A road. Providing a motorway link between the North East and the rest of England is also included in the package.

- A303/A30/A358 Corridor: This project’s investment was £2 billion which involves the transformation of an expressway and the extension of it (HM Treasury and Cabinet Office, 2016).

\section{Rail}

Britain's rail network allows millions of people to travel at a quick pace and safely for either work or leisure. In addition to this, millions of freight is moved by rail in order to reduce the amount of congestion on our road networks allowing the creation of new jobs and opening up the market stimulation economic growth (Rail Delivery Group, 2014).

The UK government's vision is to provide improved rail networks to boost economic growth and fulfil passenger expectations. The NIDP aims to improve and deliver major rail networks across England. The aim is to gain over 800 new carriages through some schemes. The objective for the year 2020 in terms of the rail sector was to commence construction/complete the following:

- HS2: The High Speed Rail 2 was a major investment by the government which was aimed at linking 8 out of the top 10 largest British cities, while being constructed, the HS2 is set to provide up to 25,000 jobs and 2,000 apprentices.

- Crossrail: This is said to be Europe's largest construction project and is to construct 118 kilometres of rail in order to increase London's rail capacity.

- Intercity Express Programme: This is a £5.7 billion investment aimed to provide new infrastructure and support the intercity routes in Britain which are busy (HM Treasury and Cabinet Office, 2016).

Based upon the few named investments taken by the UK government, it is safe to say that currently in the year 2020 there are many projects on going with set deadlines and budgets. Within the infrastructure sector, there are key parties to complete project, mainly the contractors and sub-contractors who are in the frontline of construction and are required to go on site whether it be for the actual construction of setting out coordinates provided by the designers.

\section{Covid-19}


Covid-19 is the biggest health, social and economic emergency we have faced since the Second World War. Compared to the Spanish flu back in 1918, the vulnerable people vary as with the Spanish flu, many young adults who were healthy lost their lives, about two thirds of the deaths associated with the Spanish flu were people between the ages of 18 to 50 and the highest age at which there was a peak in deaths was 28 years of age (Yan, 2020) while with the Covid-19, the elderly are more at risk. Both of these viruses, Covid-19 and the Spanish flu have similarities in how they affect the infected and how they spread, both passed on through contact, droplets, or fomites. Research in China has also highlighted that Covid-19 could be transmitted through contact with contaminated surfaces and confined spaces as it lives on surfaces for a period of time (Watterson, 2020).

During these uncertain times, there are fears that a new recession will happen, and the economy will collapse financially, measures need to be implemented within the infrastructure sector. The coronavirus was first seen in Wuhan China and was officially labelled as a pandemic by the World Health Organisation (WHO) on March 112020 (Surg, 2020). At the time of writing this paper, there have been reports of over 6.3 million Covid-19 cases worldwide and just over 374,229 deaths globally (Worldometer, 2020). This is an extremely uncertain virus which majorly affects people who are categorised as high risk having existing specific health conditions such as diabetes, cancer, in addition individuals who are aged 60 years old and over (WHO, 2020). The uncertainties of Covid-19 are still ongoing and the virus is very highly transmissible where the health workers all over the world are being overwhelmed with the high demand of care (WHO, 2020).

The UK went into Lockdown on March 23rd 2020 with rules coming into place stating the following: shopping for necessities; once a day for exercise; medical need or providing care and travelling to or from work (if you cannot work from home). These rules that have been put in place have majorly affected the way in which all industries are conducting works currently. For infrastructure projects, the impact of lockdown may vary from country to country and project to project depending on the nature, size and location. It also depends on the activities that need to be done on a project site. If the work could be executed then the health and safety risk assessments are to be done and the required personnel protective equipment need to be provided by the organisations whilst following the working guidelines during Covid-19. Due to the current pandemic there is delay in works in most projects. This would have implications on the legal contractual obligations and have a negative impact on infrastructure business operations as most works' tasks are conducted on site and require people to be present. Long and short-term planning should be undertaken to prepare for a crisis if need be.

PwC (2020) report noted that the interconnectedness, complexity and global nature of the construction industry's supply chains and workforce affect the cost and schedule of infrastructure projects during the Covid-19 pandemic. The report suggests five actions could be taken to mitigate negative results. They are to: identify critical suppliers; consider legal and financial implications; communicate clearly with all stakeholders; conduct scenario analysis; and create a contingency plan. Therefore, this paper explores the impact of Covid19 and the changes that the UK infrastructure sector has had to undertake in order to adhere to the lockdown rules while being productive.

\section{Research methodology}


Research is acquiring the new knowledge of the underlying phenomena and observable facts through the experimental or theoretical work without any particular application or use in view (Creswell and Creswell, 2018). Given the new and unexplored nature of the research problem, a qualitative research methodology was adopted. Qualitative research method provides an appropriate approach to dealing with work contexts change and the complexity of large-scale organisation change (Garcia and Gluesing, 2013). It includes considerations of the organisations of the complex multi-stakeholder, the evolution of the organisational structures and the culture, and how to meet new challenges for designing and implementing. Primary data for this research was obtained through five semi-structured interviews from three infrastructure sector organisations (See Table 1). These semi-structured interviews, aided in answering the research question: what are the impact of Covid-19 and the changes that the infrastructure sector has had to undertake in order to adhere to the lockdown rules while being productive? Semi-structured interviews provide some flexibility and it is one of the ways to obtain a realistic picture of an individual's view (Gruber et al, 2008).

Sampling is the process in which a pre-determined number of observations are selected from a larger population. Sampling is of critical importance in research, as in most cases there is a larger population that due to numerous restrictions sampling is the only viable option in obtaining reliable responses that represent the views of the wider population (Saunders et al, 2019). In this study, a purposive sampling technique was used in order to achieve representativeness (Teddlie and Tashakkori 2010). The purposive sampling technique involves drawing samples that are both easily accessible and willing to participate in a study. The study sample included directors and managers. The interviews lasted between 20 and 30 minutes. The format of these interviews was through video conferencing.

The analysis of the interviews was undertaken using Thematic Analysis. In the study, coding of the transcribed interviews involved open coding of meaning units, that is, words, phrases, sentences, paragraphs, which essentially involved labelling concepts. The emerging concepts were mapped into themes. The themes have been cross-checked on group discussions between the authors. Threats to validity were minimised through triangulation of data collection methods (interviews, observations, internal and external documents) and verification of the initial thematic codes by participants, where they judged the accuracy of data collected, though not its conclusions (Tajeddini and Mueller, 2009).

Table 1: Organizations' profiles and a breakdown of professionals who were interviewed for the study

\begin{tabular}{|c|c|c|c|c|c|c|}
\hline Organization & $\begin{array}{l}\text { Size (no. of } \\
\text { employees \& } \\
\text { approx. } \\
\text { turnover in } £ \text { ) } \\
\end{array}$ & $\begin{array}{l}\text { Organizations' } \\
\text { Operation } \\
\text { Nature }\end{array}$ & $\begin{array}{l}\text { Operation } \\
\text { Scope }\end{array}$ & $\begin{array}{l}\text { Impact on } \\
\text { Project as a } \\
\text { result of } \\
\text { Covid-19 } \\
\end{array}$ & $\begin{array}{l}\text { Responsibility of } \\
\text { interviewee in the } \\
\text { organization }\end{array}$ & $\begin{array}{l}\text { No. of } \\
\text { Interviews }\end{array}$ \\
\hline A & $\begin{array}{ll} & 26,000 \\
& \text { employees } \\
-\quad & £ 8,405 \\
& \text { million }\end{array}$ & $\begin{array}{l}\text { Engineering } \\
\text { consultancy }\end{array}$ & Regional & $\begin{array}{l}\text { Low - } \\
\text { Medium }\end{array}$ & $\begin{array}{ll}- & \text { Survey Manger } \\
\text { - } & \text { BIM Manager } \\
\text { - } & \text { Project Director }\end{array}$ & $\begin{array}{l}1 \\
1 \\
1\end{array}$ \\
\hline B & $\begin{array}{ll} & 4,700 \\
& \text { employees } \\
-\quad & £ 840.3 \\
& \text { million } \\
\end{array}$ & Utilities company & Regional & $\begin{array}{l}\text { Low - } \\
\text { Medium }\end{array}$ & - $\quad$ Project Manger & 1 \\
\hline \multirow[t]{2}{*}{$\mathrm{C}$} & $\begin{array}{ll}- & 3,400 \\
& \text { employees } \\
-\quad & £ 2.9 \text { million } \\
\end{array}$ & Utilities company & Regional & $\begin{array}{l}\text { Low - } \\
\text { Medium }\end{array}$ & - $\quad$ Project Director & 1 \\
\hline & & & & & Total & 5 \\
\hline
\end{tabular}




\section{Findings}

The current study reveals that the infrastructure sector contains many different parties and here is a breakdown of how Covid-19 has impacted each party.

\section{Management Team}

All the interviewees noted that within the infrastructure sector, the management team has a huge impact on day-to-day activities. From being involved with the planning and implementing the project plan to ensure that the objectives are completed in time and on budget. This involves liaising with the operations team and stakeholders. With the lockdown rules, this has become difficult to lead and manage the project team as they are working from home. For instance, one of the interviewees noted that:

"we cannot physically do site investigations and health and safety inspections which are required in order to make sure we are on track and the staff on site are undergoing safe work measures"

Senior management teams within the infrastructure sector are required to keep track and assist the entire site team to achieve the goals set at prior to construction. As stated by the interviewee above, the lockdown is proving to be difficult to manage the project as staff members are working from home.

\section{Operations team (site engineers, surveyors)}

On a construction project, the site team and surveyors are the key workers to complete the building and construction that has been assigned to the contractors. In the UK, there are 83,000 civil/site engineers working on various sectors and enabling the drive to finish the project as they set out the positions of assets from the designers and solve problems on site to enable the operations team/sub-contractors to build the assets. As the site team are mainly required on site, the lockdown rules in place have massively impacted the way in which they work.

The lockdown rules stated that "stay at home unless necessary and essential" and if people are high risk they should simply stay at home. All the interviewees noted that with this rule, the construction infrastructure sector has seen many site engineers/operation team members being forced to work from home as they are either at high risk or their organisations have put in place that they should work from home. This can cause a lot of delays on a project as staff cannot physically go on site and conduct works.

One of the interviewees stated that they have had difficulties in providing a service required by the engineers. Another interviewee noted that who was tasked with surveying a beam from a viaduct which was to be lifted as the viaduct was to be demolished however this task was massively delayed:

"the viaduct had to have beam number 18 lifted on the $28^{\text {th }}$ of April, this was however very difficult as we did try to lift the beam, but something was catching it leading to it not being able to move. We tried everything and tried again the following week but no results. I was tasked to survey the Beam to incorporate it into the $3 D$ model we have to visualise what was stopping the beam from being lifted, however I am classed as high risk and did not want to risk my health". 
The works were delayed for 3 weeks as the organisation kept trying to lift the beam every week without any results, on the third week the beam was finally lifted. Due to the lockdown and interviewee being high risk, this has caused the project to be three weeks behind which costs a lot of money as staff members are still receiving salary without being able to do the required tasks. Another interviewees, a manager on this task also found it difficult to liaise with his team who were conducting the works as he was working from home, with technological advanced such as video chat and meetings via online platforms have improved the communications massively as without them works would be very difficult to carry on, however at the difficult time where the beam was proving difficult to lift, the manager had no visual of what was going on as he could not go on site or could not receive the surveyed coordinated from the surveyor to visualise it digitally via the 3D model.

\section{Design team (including BIM team)}

The design team within the construction infrastructure sector comprises of the designers, design management from the contractors and digital BIM team. All the interviewees stated that the designers and BIM team members are usually not required on site as they are office based, however they work very closely with the site team in order to aid them with construction. This team is usually very digitalised especially with BIM level 2 being a minimum requirement on any public sector construction project. The members of this team are mainly not required to physically be present to conduct their tasks. Interviewee who is a BIM manager has stated that:

"Due to the essential work the construction industry had to identify methods of work which protect the workforce during the COVID-19 outbreak. This has led to a dramatic uptake in the use of digital tools. These include tools for communication, centralised data storage and modelling. Due to this uptake the BIM sector has been able to harness this new motivation to adopt new technologies and direct it to adhere to the relevant standards, such as the use of Common Data Environment, use of a centralised federated model and adhering to transmittal procedures”.

The main objective for the BIM team on a project is to drive the digitisation of their organisation and project. As the teams are not required to be physically on site to undertake their roles and responsibilities, the lockdown rules have not majorly affected their day to day tasks. However as noted above, the manager could have enabled the Design/BIM team to be able to assist those on site to be able to pinpoint the issues that were being faced with lifting the beam. Despite that scenario, the BIM/Design teams have been extremely useful as being forced to use digital aids such as the 3D design model to assist the rest of the organisation teams to visualise the project within team meetings meant that the BIM/Design team were requested for meetings and allowed them to benefit from their resources.

\section{New staff}

As Naysmith (ICE, 2020) noted that infrastructure will remain crucial in supporting growing communities and noted that: "Before the world was hit by Covid-19, we had a shortage of skills and talent to deliver environmentally important and engineering critical projects. This need for talent has not gone away in light of the current humanitarian crisis, it has potentially increased”. The infrastructure sector being at its peak with billions being invested into it will require new staffs that are competent to undertake the objectives set for the project. The interviewees noted that many projects are set to commence their construction stage in the year 2020 and with the budget already set and the duration of the project and dates agreed, 
henceforth works must carry on. Recruiting staff members during this uncertain time has been a difficult process as candidates cannot attend interviews in person leading to the whole recruitment process being virtual with the use of digital technologies.

In the UK infrastructure sector, it is a procedure to undertake an induction prior to any new starter on a project and the individual must also undertake a drugs and alcohol test prior to commencing work of that project. With the pandemic and lockdown rules, this is a procedure that cannot go ahead. As projects are still hiring or have hired new staff to commence during these times, the new staff members would not be able to follow this procedure as they are to work from home. This is a difficult scenario as new staff member do not get the opportunity to meet their teams face-to-face and which can affect the way in which they collaborate and communicate.

\section{Existing workforce protection}

In the interviewed organisations all the interviewees stated three factors that were considered to protect the existing workforce protection. They are policy and management, communication and health and safety. Management within organisations have introduced a few policy changes in which the workforce can follow social distancing rules while being able to conduct works on site.

Usually on a site, there are site offices where people sit relatively close to each other and when taking a trip to the construction site there are vans available for the gangs that are to conduct the works. As a protective measure, the sites on current ongoing projects have taken precaution to minimise the amount of people sharing vans to comply with the 2 meter social distancing rule, hand sanitisers have also been available throughout the site and in vans and work vehicles.

In addition to this, most of staff have been asked to work from home which increases the use of technology and mobile phone in order for senior staff member to be able to communicate and collaborate with their team that are to be on site and undertake the works. Health and safety of the workers are being closely managed in order to minimise human contact while operating a safe site with the reduction of the amount of staff members on site.

\section{Supply chain}

All the interviewees noted that supply chain is affected in the infrastructure sector from the workers and the supply of construction materials perspective. Supply chain have been going through many challenges as many staff members usually commute and stay where the project is being undertaken. As a result of Covid-19, both the supply chain and staff members within the organisations who usually stay during the week in order to attend work have faced challenges with hotel accommodation as hotels are the main source of accommodation provision for construction workers.

The supply of construction materials has also been affected. At the start of the Covid-19 suppliers were hesitant at what to do in terms of travelling to different sites to delivery materials, during the first months that Covid-19 was at a rise, most projects implemented policies that banned any visitors from coming to site, as time passed, new systems were introduced in terms of materials delivery which follow the guidelines for the lockdown and 
social distancing measures in order to keep the works going while ensuring the safety of both suppliers and site office staff members.

Engagement with the supplier as with all other collaboration has been shifted to technologies which is providing an acceleration in innovation with the use of digital strategies aiding in dealing with the restrictions that have come into place with Covid-19.

\section{Client}

Clients within the construction infrastructure sector are usually not in the site offices and tend to conduct visits to the project if necessary. Upon the start of Covid-19, clients who worked within their own offices also took the initiative to start working from home during the end of March 2020. As previously mentioned, technologies such as Microsoft Teams have been used to communicate with contractors, designers, and other supply chain team members.

At this uncertain time, the clients need to have confidence in the contractors to deliver the project as promised. As there is less workforce and staff on site, this confidence within the clients must come from trusting the workforce to complete the project without providing risks to the employees. Clients are mainly focused on maintaining the workforce safely and to minimise the impact on the supply chain, staff, and customers. To provide safer working conditions within the infrastructure road sector, most clients for the projects have issued key worker status to their workers that are to be on site, namely the site engineers, and site office staff.

"We have provided the ability for testing for the virus to construction workers on our Strategic Road Networks (SRN). In addition, guidance on the coronavirus testing, including who is eligible for a test, how to get tested and the different types of test available."

One of the interviewees who work for the clients has elaborated on how the virus testing has been extended to all construction workers to ensure that staff members are safe. Testing for the virus has not been easily available for everyone within the UK, however with the clients of SRN's providing key worker status for their project staff members and other parties within the organisation, this enables workers to take the initiative of being able to request testing for the virus. The clients for the projects have taken measures to adjust their commercial terms in order to adapt to the challenges produced due to the virus. Place of work requirements have been altered allowing people to work from home which adheres to their safety obligations to the contractors, designers and the supply chain.

\section{Discussions}

Organisations within the infrastructure sector have put strategies in place in order to comply with lockdown and not risk their employees and stakeholders lives. Currently most infrastructure projects have allowed their staff members to work from home and with the lockdown rules easing; strategies have been put in place to make the offices workable with safe distancing for employees. Table 2 summarises the solutions implemented to improve challenges being faced by infrastructure organisations due to Covid-19. 
Table 2: Solutions implemented to improve challenges being faced by infrastructure organisations due to Covid-19

\begin{tabular}{|c|c|c|c|c|c|}
\hline \multirow[t]{2}{*}{$\begin{array}{l}\text { Challenges } \\
\text { observed }\end{array}$} & \multirow[t]{2}{*}{$\begin{array}{l}\text { Parties mainly } \\
\text { affected }\end{array}$} & \multirow[t]{2}{*}{ Solution implemented to enable works } & \multicolumn{3}{|c|}{$\begin{array}{l}\text { Organisations who } \\
\text { have implemented the } \\
\text { solutions }\end{array}$} \\
\hline & & & A & B & C \\
\hline $\begin{array}{l}\text { Collaboration and } \\
\text { communication. }\end{array}$ & $\begin{array}{l}\text { Client, } \\
\text { Contractors, } \\
\text { Designers and } \\
\text { Supply Chain }\end{array}$ & $\begin{array}{l}\text { The organisations resulted in using digital means } \\
\text { to communicate and collaborate. As most staff } \\
\text { members are working from home, the use of } \\
\text { technologies and software's such as Microsoft } \\
\text { Teams boosted within the organisations in order } \\
\text { to enable discussion and works. }\end{array}$ & • & $\bullet$ & $\bullet$ \\
\hline $\begin{array}{l}\text { Commuting for } \\
\text { work and staying at } \\
\text { workplace location. }\end{array}$ & $\begin{array}{l}\text { Supply Chain } \\
\text { and Contractors }\end{array}$ & $\begin{array}{l}\text { This challenge sees a lot of staff members finding } \\
\text { it difficult to travel and stay at the location that } \\
\text { their project is being undertaken. As a solution } \\
\text { client have approved for the staff members within } \\
\text { the organisations to work from home unless } \\
\text { essential to travel to site. }\end{array}$ & & • & \\
\hline $\begin{array}{l}\text { Working as part of } \\
\text { a team on site. }\end{array}$ & $\begin{array}{l}\text { Supply Chain } \\
\text { and Contractors }\end{array}$ & $\begin{array}{l}\text { The site team share vans and vehicles to travel to } \\
\text { site to undertake works, the measures taken to } \\
\text { abide by the social distancing rules is limiting the } \\
\text { amount of people in vehicles and in the office in } \\
\text { order to enable them to follow the social } \\
\text { distancing rules. }\end{array}$ & & $\bullet$ & $\bullet$ \\
\hline $\begin{array}{l}\text { Stakeholder } \\
\text { engagement. }\end{array}$ & $\begin{array}{l}\text { Clients, } \\
\text { Contractors, } \\
\text { Designers and } \\
\text { Supply chain. }\end{array}$ & $\begin{array}{l}\text { Stakeholder engagement has been put to a pause } \\
\text { in terms of engagement with the community } \\
\text { however key stakeholders are still in contact via } \\
\text { digital tool which is keeping then informed and } \\
\text { enabling collaboration and communication. }\end{array}$ & $\bullet$ & $\bullet$ & $\bullet$ \\
\hline
\end{tabular}

As shown in Table 2, organisations $\mathrm{A}$ and $\mathrm{C}$ have not had a unanimous implementation of the solutions compared to organisation B. Organisation A and C have most of their staff members are present in the offices, though safe distancing has been implemented within the office, employees within the project only managed to work from home for three weeks during the initial lockdown announcement before returning to offices though lockdown continued and other organisations remained working from home.

All three organisations have taken the initiative to provide one-way systems on offices and ensure that seats for employees are at least two meters apart even though the office staff have not returned on site yet and are still working from home. This has been put into place to plan for future opening of the offices as the UK government is easing the lockdown rules.

Two organisations noted that there are processes that cover disasters in the current workplace such as: IT breaches; exceptional financial issues; and major sickness and therefore it enabled companies to support their staff. However, the Covid-19 outbreak has been unexpected and grew rapidly. The infrastructure sector has had to alternate the way in which works are currently being carried out as a result of measures introduced by the UK government.

The Covid-19 pandemic has however boosted the use of digital advances within the three infrastructure organisations. The industry is currently going through its $4^{\text {th }}$ industrial revolution which is focused on digitalising the industry. This $4^{\text {th }}$ industrial revolution has 
seen a massive adoption not just in the construction sector but through different organisations such as education, social etc. of technologies.

The infrastructure sector has resulted in the use of 3D models and digital means to communicate since the lockdown was put in place in the UK in order to be able to keep works ongoing and provide less risk of loosing costs and time for the projects which have already commenced or are about to commence. Induction process for projects have also moved to online systems which are being used to inform staff members on what is going on within their projects remotely from home.

Within the construction infrastructure sector, the changes that have been found in the results are inconvenient however manageable. The clients have also considered the safety of their contractors and other parties of the organisation and put some measures in place where they are to be managed as normal as they are still undergoing works.

\section{Conclusion and recommendations}

Today, infrastructure sector organisations can succeed only if they are genuinely 'value-led' and adopt a holistic approach to address once-in-a-generation crisis. Covid-19 is the biggest health, social and economic emergency we have faced since the Second World War. Covid19 continues to spread rapidly around the world. Almost every country has reported cases, but the burden is asymmetrically distributed. During these uncertain times, there are fears that a new recession will happen, and the economy will collapse financially, measures need to be implemented within the infrastructure sector. Long and short-term planning should be undertaken to prepare for a crisis if need be. Governments around the world see infrastructure investment as key to re-booting economic growth. Therefore, post-Covid-19 society will return once more to dealing with the sustainable infrastructure development for the societal improvement.

This paper provides a richer insight into the understanding and awareness of the impact of Covid-19 and the changes that the infrastructure sector has had to undertake in order to adhere to the lockdown rules while being productive. This study contributes towards informing policymakers on some lessons learned from the management of the Covid-19 from an infrastructure sector perspective. This paper reports the current infrastructure project going on which have been affected by Covid-19 and its impact on management team; operations team (site engineers, surveyors); design team (including BIM team); new staff; existing workforce; supply chain and clients. The lockdown is proving to be difficult to manage the project as staff members are working from home. This leads to a delays on a project activities as staff cannot physically go on site and conduct works. The directors and managers are finding difficult to manage their teams. However, technological tools such as video chat and meetings via online platforms have proven to be most effective in communications with project teams. The BIM/Design teams have been extremely useful as the 3D design models helps to visualise the project within team meetings. However, induction to any new starter is proving to be difficult manage with the pandemic and lockdown as it involves a drugs and alcohol test prior to commencing work of that project.

It is vital that the infrastructure sector create a development plan as there are a lot of projects which have been planned and are to keep going as budgets have been set and so have time frames in which to complete the projects. The pandemic could potentially delay projects which could cost organisations a lot of extra costs as delays are likely at this stage. It is 
evident that the infrastructure sector undertakes whatever is necessary in order to keep staff safe in terms of not risking their lives, while adapting to this new way of working and trying to deliver the project as promised as if projects get delayed, this can send organisation into liquidation as a result of too much extra costs and not enough time to complete projects as planned. Table 3 presents the implications for decision makers within the infrastructure sector business to rethink and act.

Table 3: Implications for decision makers within the infrastructure sector business

\begin{tabular}{|c|c|}
\hline Implications & Recommendations for decision makers \\
\hline $\begin{array}{l}\text { Immediate stakeholder } \\
\text { challenges }\end{array}$ & $\begin{array}{l}\text { Address the immediate challenges that Covid-19 represents to workforce, design team, } \\
\text { contractors, clients, stakeholder and supply chain. }\end{array}$ \\
\hline Short-term cash flow issues & $\begin{array}{l}\text { Address short-term cash flow management and broader resiliency issues during Covid- } \\
19 \text { related lockdown and economic knock-on effects. }\end{array}$ \\
\hline Business return plan & $\begin{array}{l}\text { Create detailed plan to return business to scale quickly as Covid-19 situation evolves } \\
\text { and the knock-on effects become clearer. }\end{array}$ \\
\hline Reimage post-lockdown & $\begin{array}{l}\text { Reimage the possible post-lockdown workplace rules and implications for value chain } \\
\text { (workforce, design team, contractors, clients, stakeholder and supply chain. }\end{array}$ \\
\hline Support employees & Support and protect employees in this challenging times of Covid-19. \\
\hline Regulatory issues & $\begin{array}{l}\text { Be clear about how regulatory and competitive environments in the infrastructure sector } \\
\text { may change. }\end{array}$ \\
\hline Clear communication & $\begin{array}{l}\text { Organisations need to increase communication, balancing the needs of the business } \\
\text { with expectation setting and morale building, so employees know that their well-being } \\
\text { is considered as a top priority. }\end{array}$ \\
\hline Reshape & $\begin{array}{l}\text { The infrastructure sector organisations need to reshape their existing strategy in-line } \\
\text { with the Covid-19 issues. }\end{array}$ \\
\hline Increase collaboration & $\begin{array}{l}\text { To address Covid-19 issues, knowledge is increasingly being accessed and shared } \\
\text { across sectors and national boundaries. Therefore, there is a need for cross-sector } \\
\text { collaboration to capture and share best and worst practices related to managing Covid- } \\
19 \text { issues within infrastructure sector. }\end{array}$ \\
\hline Education and training & $\begin{array}{l}\text { The infrastructure sector should liaise with universities in the future to ensure the right } \\
\text { skill sets are developed and also need to improve in-house training so that management } \\
\text { of once-in-a-generation crisis management like Covid-19 becomes a matter of basic } \\
\text { knowledge for most employees. Therefore, the UK physical infrastructure related } \\
\text { education curricula must integrate the crisis management aspect into its courses. }\end{array}$ \\
\hline Crises response leadership & $\begin{array}{l}\text { The Covid-19 pandemic has placed extraordinary demands on leaders in business and } \\
\text { beyond. During a crisis, which is ruled by unfamiliarity and uncertainty, effective } \\
\text { responses are largely improvised. Effective leadership is one of the most important } \\
\text { aspects of managing crisis. Therefore, there is a need to develop and deliver bespoke } \\
\text { crisis-response leadership programmes with respect to infrastructure sector. }\end{array}$ \\
\hline Cultural change & $\begin{array}{l}\text { Cultural hallmarks are threatened by the Covid-19 crisis for the infrastructure sector. A } \\
\text { distributed, remote-working model makes more difficult for the industry. Managers } \\
\text { need to proactively communicate effectively with various stakeholders to ensure clear } \\
\text { ownership. Change and dynamic relationships are integral to business systems, and the } \\
\text { culture of an organisation plays a vital role in driving the behaviours and attitudes that } \\
\text { support rather than hinder change. Therefore, UK infrastructure organisations need to } \\
\text { engage in a dramatic culture change in order to respond to Covid- } 19 \text { challenges such as } \\
\text { social distancing, self-isolation, remote-working and virtual team meetings. }\end{array}$ \\
\hline
\end{tabular}


Despite the novel insights provided by this study, it has some limitations. Given that the research reported in this paper is a preliminary study and exploratory by nature, the results presented are only tentative and of limited value for the purpose of generalisability. Furthermore, the findings of this paper are limited to the UK infrastructure sector only; as such, the level of generalisability outside this context may be very limited. However, we argue that the results obtained are useful to similar developed countries.

\section{References}

Akintoye, A. and Renukappa, S., (2013), The UK Water Industry Infrastructure Governance and Procurement, in the book titled Water Governance: An Evaluation of Alternative Architectures, Edited by Asanga Gunawansa and Lovleen Bhullar, Edward Elgar Publishing, U.K., ISBN: 978-1-781-00641-2.

Berg, C. (2015), How far do roads contribute to development? available at: https://www.weforum.org/agenda/2015/12/how-far-do-roads-contribute-to-development/ (accessed 1 May 2020).

Creswell, J. W and Creswell, J. D., (2018), Research design: qualitative, quantitative, and mixed method Approaches, Los Angeles: Sage. ISBN: 9781506386768.

Garcia D. and Gluesing J.C, (2013), Qualitative research methods in international organizational change research, Journal of Organizational Change Management, Vol. 26, No. (2, pp. 423 - 444. https://doi.org/10.1108/09534811311328416

Grigg, N. S. (2010), Infrastructure Finance - The Business of Infrastructure for a Sustainable Future, John Wiley and Sons, New York, USA, ISBN: 978-0-470-48178-3.

Gruber, T., Szmigin, I., Reppel, A.E. and Voss, R. (2008), Designing and conducting online interviews to investigate interesting consumer phenomena, Qualitative Market Research, 11(3), 256274. https://doi.org/10.1108/13522750810879002

Helm, D., Wardlaw, J., and Caldecott, B., (2010), Delivering a 21st Century Infrastructure for Britain, Policy Exchange, London, U.K., ISBN: 978-1-906097-55-4.

HM Treasury (2013), National Infrastructure Plan 2013, HM treasury office, London, ISBN 978-1-909790-575.

HM Treasury and Cabinet Office (2016), National Infrastructure Delivery Plan 2016-2021, London, UK. available

at:

https://assets.publishing.service.gov.uk/government/uploads/system/uploads/attachment_data/file/520086/29045 69_nidp_deliveryplan.pdf

ICE (2013), Realising a World Class Infrastructure - ICE's Guiding Principles of Asset Management, Institution of Civil Engineers, London, U.K., available at: https://www.ice.org.uk/ICEDevelopmentWebPortal/media/Documents/Disciplines\%20and\%20Resources/Best \%20Practice/Guiding-Principles-of-Asset-Management-3.pdf

ICE (2020), Civil engineering is more important than ever, available at: https://www.ice.org.uk/news-andinsight/latest-ice-news/civil-engineering-is-more-important-than-ever, (accessed 3 May 2020).

Kynge, J. and Lockett, H. (2020), From cover-up to global donor: China's soft power play, available at: https://www.ft.com/content/efdec278-6d01-11ea-9bca-bf503995cd6f, (accessed 20 April 2020).

PwC (2020), Five actions can help mitigate risks to infrastructure projects amid COVID-19, https://www.pwc.com/gx/en/industries/capital-projects-infrastructure/publications/infrastructure-covid-19.html (accessed 30 May 2020).

Rail Delivery Group (2014), What is the contribution of rail to the UK economy, London: Oxera. Available at: https://www.oxera.com/wp-content/uploads/2018/07/RDG-booklet-Final-Sept-15.pdf.pdf

Reynolds, M. and Weiss, S. (2020), How coronavirus started and what happens next, explained, available at: https://www.wired.co.uk/article/china-coronavirus, (accessed 10 April 2020).

Saunders, M., Thornhill, A. and Lewis, P. (2019), Research methods for business students, Harlow: Pearson Education. ISBN 9781292208787. 
Standard \& Poor’s Ratings Services (2014), Global Infrastructure: How to fill a $\$ 500$ billion hole, McGraw Hill Financial, New York, USA, available at: https://www.infrapppworld.com/report/global-infrastructure-how-tofill-a-500-billion-hole-standard-poor-s

Surg, I. J. (2020), The Socio-Economic Implications of the Coronavirus and COVID-19 Pandemic: A Review, International Journal of Surgery, London, UK. Vol. 78, June 2020, pp. 185-193, https://doi.org/10.1016/j.ijsu.2020.04.018

Tajeddini, K. and Mueller, S.L. (2009), Entrepreneurial characteristics in Switzerland and the UK: A comparative study of techno-entrepreneurs, Journal of International Entrepreneurship, 7(1), pp. 1-25. DOI: 10.1007/s10843-008-0028-4.

Teddlie, C. and Tashakkori, A. (2010), Major issues and controversies in the use of mixed methods in the social and behavioural science, In Handbook of mixed methods in social and behavioural research. Thousand Oaks, Sage, UK. ISBN: 9781412972666.

Watterson, A. (2020), COVID-19 in the UK and Occupational Health and Safety: Predictable not Inevitable Failures by Government, and Trade Union and Nongovernmental Organization Responses, NEW SOLUTIONS: A Journal of Environmental and Occupational Health Policy, pp. 1-9, https://doi.org/10.1177\%2F1048291120929763.

Weber, B. and Alfen, H. W., (2016), Infrastructure as an Asset Class: Investment Strategies, Project Finance and PPP, John Wiley and Sons, New York, USA, ISBN: 978-1-119-22654-3.

WHO (2020), World Health Organisation- a Coordinated Global Research Roadmap: 2019 Novel Coronavirus, available at: https://www.who.int/who-documents-detail/a-coordinated-global-research-roadmap (accessed 10 April 2020).

Worldometer (2020), COVID-19 coronavirus pandemic, available at: https://www.worldometers.info/coronavirus/, (accessed 1June 2020).

Yan, H. (2020), The Spanish flu killed more than 50 million people. These lessons could help avoid a repeat with coronavirus, available at: https://edition.cnn.com/2020/04/16/health/spanish-flu-coronavirus-lessonslearned/index.html, (accessed 1June 2020). 